Zabytkoznawstwo i Konserwatorstwo XIII, Torun 2011

\title{
Badanie przyczepności lakierów metodą siatki nacięć
}

$\mathrm{D}$ obra przyczepność to jedna z podstawowych cech, wymaganych od lakierów wykorzystywanych w sztuce, zarówno w działaniach o charakterze twórczym, jak i konserwatorskim.

W praktyce są stosowane dwie metody badania przyczepności: pierwsza, polegająca na ocenie przyczepności pojedynczej powłoki lub systemu powłok farb i lakierów na podstawie minimalnego naprężenia rozciagającego, potrzebnego do rozdzielenia lub oderwania powłoki prostopadle od podłoża ${ }^{1}$, i druga, polegająca na określeniu stopnia odporności powłoki z farb na odwarstwienie od podłoża w wyniku nacięcia powłoki w postaci prostokątnej siatki, przechodzącej przez powłokę do podłoża ${ }^{2}$. W niniejszym artykule zostały przedstawione wyniki badań przeprowadzonych za pomocą drugiej metody.

W działaniach o charakterze artystycznym w malarstwie, rzemiośle artystycznym, konserwacji stosujemy szeroką gamę gotowych produktów dostępnych w handlu i przygotowanych we własnym zakresie. Zastana-

1 Polska norma PN-EN ISO 4624 Farby i lakiery. Próba odrywania do oceny przyczepności. Norma europejska EN ISO 4624:2003 ma status polskiej normy.

2 Polska norma PN-EN ISO 2409 Farby i lakiery. Badanie metoda siatki nacięć. Norma europejska EN ISO 2409:2007 ma status polskiej normy. 
wiamy się nad ich właściwościami, nad tym, czy użyty przez nas materiał daje nam pewność trafnego doboru. W prowadzonych od lat badaniach autor podją próbę wskazania tych o najlepszych właściwościach. Zanalizował lakiery na bazie żywic syntetycznych, jak i naturalnych, a także dużą liczbę lakierów opartych na recepturach historycznych.

W przygotowanych kompozycjach lakierowych, obok tradycyjnych rozpuszczalników, do rozpuszczania żywic naturalnych autor wykorzystał 1-metoksy-2-propanol i dodatek eteru metylowego glikolu dipropylenowego - rozpuszczalniki używane do rozpuszczania żywic sztucznych. Zastosowanie ich do rozpuszczania żywic naturalnych jest podyktowane poszukiwaniem lakierów o optymalnych właściwościach, odpowiedniej rozlewności, czasie wysychania pozwalającym na równomierne nanoszenie na powierzchnię malarską bądź złoconą obiektu. Przeprowadzone próby przyniosły zadowalające efekty.

Przebieg badania: Badanie przeprowadzono zgodnie z opisem zawartym w normie PN-EN ISO 2409. Metoda polega na określeniu przyczepności za pomocą siatki nacięć wykonanej przy użyciu noża krążkowego ${ }^{3}$, na którego obwodzie umieszczono 6 równolegle ułożonych ostrzy w odległościach $1 \mathrm{~mm}$. Odstępstwem było zastosowanie jako podłoża, zamiast zalecanych płytek stalowych, płytek mosiężnych, zbliżonych do rzeczywistego obiektu pozłoconego folią mosiężną, tzw. szlagmetalem.

Przygotowanie próbek: Z taśmy mosiężnej o grubości $0,3 \mathrm{~mm}$ przycięto płytki mosiężne o wymiarach $100 \times 50 \mathrm{~mm}$. Po wyprostowaniu i oczyszczeniu powierzchni płytek acetonem i wysuszeniu naniesiono na nie za pomoca pędzla nylonowego lakiery, każdy na 2 płytki. Zabieg przeprowadzono w temperaturze $23 \pm 2^{\circ} \mathrm{C}$ i wilgotności względnej powietrza $40 \pm 5 \%$. Płytki z naniesionymi lakierami poddano procesowi suszenia trwającemu 5 miesięcy.

Przebieg badania: Na płytkach wykonywano nacięcia równoległe nożem krążkowym, a następnie pod kątem prostym kolejne nacięcia przecinające poprzednie. Powstawała siatka nacięć składająca się z 25 kwadratów; wykonano po 6 siatek nacięć. Płytki oczyszczono szczoteczka, potem naklejono taśmę samoprzylepna, którą dociśnięto palcem. Po upływie 5 minut taśmę oderwano. Oceny powstałych uszkodzeń dokonywano

3 Nóż krążkowy Elkometer 1542. 
za pomoca szkła o trzykrotnym powiększeniu oraz pod mikroskopem. Liczba i procent powstałych ubytków oraz stopień uszkodzenia/ubytku określano w sześciostopniowej skali od 0 do 5 podanej w normie ${ }^{4}$.

\section{Lakiery z żywic sztucznych}

Przy badaniu lakierów na bazie żywic sztucznych zastosowano 10\% i 20\% stężenia w celu określenia wpływu stężenia na przyczepność.

Tab. 1. Lakiery z żywic sztucznych - badanie po 5 miesiącach od nałożenia (temp. $22^{\circ} \mathrm{C}$, wilg. $\left.40 \%\right)$

\begin{tabular}{|c|c|c|c|}
\hline $\mathrm{Nr}$ & Nazwa lakieru/kompozycji & Wynik & Uwagi \\
\hline 1 & 2 & 3 & 4 \\
\hline 1 & $20 \%$ Paraloid B-44 w acetonie & 3,7 & $\begin{array}{l}\text { Powierzchnia błyszcząca. Po oderwaniu taśmy } \\
\text { bez zmian. Warstwa odpada w formie błony }\end{array}$ \\
\hline 1 ' & 10\% Paraloid B-44 w acetonie & 4,5 & $\begin{array}{l}\text { Powierzchnia błyszcząca. Po oderwaniu taśmy } \\
\text { bez zmian. Warstwa silnie odpada w formie } \\
\text { błony }\end{array}$ \\
\hline 2 & $20 \%$ Paraloid B-44 w toluenie & 2,8 & $\begin{array}{l}\text { Powierzchnia błyszcząca. Po oderwaniu taśmy } \\
\text { bez zmian. Warstwa odpada w formie błony }\end{array}$ \\
\hline $2^{\prime}$ & $10 \%$ Paraloid B-44 w toluenie & 2,7 & $\begin{array}{l}\text { Powierzchnia błyszcząca. Po oderwaniu taśmy } \\
\text { bez zmian. W cieńszej warstwie mniejszy ubytek }\end{array}$ \\
\hline 3 & 20\% Paraloid B-44 w 1-1-metoksy-2-propanolu & 2,3 & $\begin{array}{l}\text { Powierzchnia błyszcząca. Po oderwaniu taśmy } \\
\text { bez zmian. Warstwa odpada w formie błony }\end{array}$ \\
\hline 3' & 10\% Paraloid B-44 w 1-1-metoksy-2-propanolu & 2,6 & $\begin{array}{l}\text { Powierzchnia błyszcząca. Po oderwaniu taśmy } \\
\text { bez zmian. Warstwa odpada w formie błony }\end{array}$ \\
\hline 4 & $20 \%$ Paraloid B-48N w acetonie & 0,3 & $\begin{array}{l}\text { Powierzchnia błyszcząca. Po oderwaniu taśmy } \\
\text { bez zmian. Bardzo dobra przyczepność }\end{array}$ \\
\hline 4 ' & $10 \%$ Paraloid B-48N w acetonie & 0,2 & $\begin{array}{l}\text { Powierzchnia błyszcząca. Po oderwaniu taśmy } \\
\text { bez zmian. Bardzo dobra przyczepność }\end{array}$ \\
\hline 5 & $20 \%$ Paraloid B-48N w toluenie & 0,1 & $\begin{array}{l}\text { Powierzchnia błyszcząca. Po oderwaniu taśmy } \\
\text { bez zmian. Bardzo dobra przyczepność }\end{array}$ \\
\hline $5^{\prime}$ & $10 \%$ Paraloid B-48N w toluenie & 0,0 & $\begin{array}{l}\text { Powierzchnia błyszcząca. Po oderwaniu taśmy } \\
\text { bez zmian. Bardzo dobra przyczepność }\end{array}$ \\
\hline 6 & 20\% Paraloid B-48N w 1-metoksy-2-propanolu & 0,2 & $\begin{array}{l}\text { Powierzchnia błyszcząca. Po oderwaniu taśmy } \\
\text { bez zmian. Bardzo dobra przyczepność }\end{array}$ \\
\hline $6^{\prime}$ & 10\% Paraloid B-48N w 1-metoksy-2-propanolu & 0,0 & $\begin{array}{l}\text { Powierzchnia matowa, zacieki. Bardzo dobra } \\
\text { przyczepność }\end{array}$ \\
\hline 7 & 20\% Paraloid B-67 w benzynie lakowej & 0,3 & $\begin{array}{l}\text { Powierzchnia błyszcząca. Po oderwaniu taśmy } \\
\text { bez zmian. Bardzo dobra przyczepność }\end{array}$ \\
\hline
\end{tabular}

4 Skala podstawowa oceny przyczepności metodą siatki nacięć (norma polska PN-EN ISO 2409). 
Ciagg dalszy tab. 1

\begin{tabular}{|c|c|c|c|}
\hline 1 & 2 & 3 & 4 \\
\hline 7 ' & $10 \%$ Paraloid B-67 w benzynie lakowej & 0,0 & $\begin{array}{l}\text { Powierzchnia błyszcząca. Po oderwaniu taśmy } \\
\text { bez zmian. Bardzo dobra przyczepność }\end{array}$ \\
\hline 8 & 20\% Paraloid B-72 w acetonie & 1,4 & $\begin{array}{l}\text { Powierzchnia błyszcząca. Po oderwaniu taśmy } \\
\text { bez zmian }\end{array}$ \\
\hline 8 ' & 10\% Paraloid B-72 w acetonie & 2,9 & Warstwa ma matowe smugi \\
\hline 9 & 20\% Paraloid B-72 w toluenie & 3,8 & $\begin{array}{l}\text { Powierzchnia błyszcząca. Po oderwaniu taśmy } \\
\text { bez zmian. Warstwa odpada w formie błony }\end{array}$ \\
\hline 10 & 20\% Paraloid B-72 w 1-1-metoksy-2-propanolu & 3,0 & $\begin{array}{l}\text { Powierzchnia błyszcząca. Po oderwaniu taśmy } \\
\text { bez zmian }\end{array}$ \\
\hline $10^{\prime}$ & 10\% Paraloid B-72 w 1-1-metoksy-2-propanolu & 2,8 & $\begin{array}{l}\text { Powierzchnia błyszcząca. Po oderwaniu taśmy } \\
\text { bez zmian }\end{array}$ \\
\hline 11 & 20\% Paraloid B-72 w alkoholu etylowym & 4,7 & $\begin{array}{l}\text { Powierzchnia błyszcząca. Po oderwaniu taśmy } \\
\text { bez zmian. Warstwa odpada w formie błony }\end{array}$ \\
\hline $11^{\prime}$ & 10\% Paraloid B-72 w alkoholu etylowym & 3,1 & $\begin{array}{l}\text { Powierzchnia błyszcząca. Po oderwaniu taśmy } \\
\text { bez zmian. W cienkiej warstwie mniejsze ubytki }\end{array}$ \\
\hline 12 & 20\% Paraloid B-82 w acetonie & 3,1 & $\begin{array}{l}\text { Powierzchnia błyszcząca. Po oderwaniu taśmy } \\
\text { bez zmian }\end{array}$ \\
\hline $12^{\prime}$ & 10\% Paraloid B-82 w acetonie & 2,8 & $\begin{array}{l}\text { Powierzchnia błyszcząca. Po oderwaniu taśmy } \\
\text { bez zmian }\end{array}$ \\
\hline 13 & 20\% Paraloid B-82 w toluenie & 3,4 & $\begin{array}{l}\text { Powierzchnia błyszcząca. Po oderwaniu taśmy } \\
\text { bez zmian }\end{array}$ \\
\hline $13^{\prime}$ & 10\% Paraloid B-82 w toluenie & 3,1 & $\begin{array}{l}\text { Powierzchnia błyszcząca. Po oderwaniu taśmy } \\
\text { bez zmian }\end{array}$ \\
\hline 14 & 20\% Paraloid B-82 w 1-metoksy-2-propanolu & 3,4 & $\begin{array}{l}\text { Powierzchnia błyszcząca. Po oderwaniu taśmy } \\
\text { bez zmian }\end{array}$ \\
\hline $14^{\prime}$ & 10\% Paraloid B-82 w 1-metoksy-2-propanolu & 2,4 & $\begin{array}{l}\text { Warstwa matowa. Po oderwaniu taśmy } \\
\text { bez zmian }\end{array}$ \\
\hline 15 & 20\% Paraloid B-82 w alkoholu etylowym & 3,7 & $\begin{array}{l}\text { Występują zmatowienia w warstwie. Po oderwa- } \\
\text { niu bez zmian }\end{array}$ \\
\hline 15 & 10\% Paraloid B-82 w alkoholu etylowym & 3,3 & $\begin{array}{l}\text { Występują zmatowienia w warstwie. Po oderwa- } \\
\text { niu bez zmian }\end{array}$ \\
\hline 16 & 20\% Laropal A 81 w acetonie & 2,6 & $\begin{array}{l}\text { Powierzchnia błyszcząca. Po oderwaniu taśmy } \\
\text { lekko matowa. Lakier kruchy }\end{array}$ \\
\hline $16^{\prime}$ & 10\% Laropal A 81 w acetonie & 2,2 & $\begin{array}{l}\text { Powierzchnia błyszcząca. Po oderwaniu taśmy } \\
\text { lekko matowa. Lakier kruchy }\end{array}$ \\
\hline 17 & $20 \%$ Laropal A 81 w toluenie & 3,0 & $\begin{array}{l}\text { Powierzchnia błyszcząca. Po oderwaniu taśmy } \\
\text { lekko matowa. Lakier kruchy }\end{array}$ \\
\hline $17^{\prime}$ & $10 \%$ Laropal A 81 w toluenie & 2,5 & $\begin{array}{l}\text { Powierzchnia błyszcząca. Po oderwaniu taśmy } \\
\text { lekko matowa. Lakier kruchy }\end{array}$ \\
\hline 18 & 20\% Laropal A 81 w alkoholu etylowym & 2,8 & $\begin{array}{l}\text { Powierzchnia błyszcząca. Po oderwaniu taśmy } \\
\text { lekko matowa. Lakier kruchy }\end{array}$ \\
\hline 18 ' & 10\% Laropal A 81 w alkoholu etylowym & 2,8 & $\begin{array}{l}\text { Powierzchnia błyszcząca. Po oderwaniu taśmy } \\
\text { lekko matowa. Lakier kruchy }\end{array}$ \\
\hline 19 & $20 \%$ Laropal A 81 w 1-1-metoksy-2-propanolu & 1,3 & $\begin{array}{l}\text { Powierzchnia błyszcząca. Po oderwaniu taśmy } \\
\text { matowa. Lakier kruchy }\end{array}$ \\
\hline
\end{tabular}


Ciag dalszy tab. 1

\begin{tabular}{|c|c|c|l|}
\hline 1 & \multicolumn{1}{|c|}{2} & 3 & \multicolumn{1}{|c|}{4} \\
\hline 20 & $20 \%$ Regalrez 1094 w benzynie lakowej & 2,8 & $\begin{array}{l}\text { Powierzchnia błyszcząca. Po oderwaniu taśmy } \\
\text { lekko matowa. Lakier kruchy }\end{array}$ \\
\hline 20 & $10 \%$ Regalrez 1094 w benzynie lakowej & 2,8 & $\begin{array}{l}\text { Powierzchnia błyszcząca. Po oderwaniu taśmy } \\
\text { lekko matowa. Lakier kruchy }\end{array}$ \\
\hline
\end{tabular}

Przeprowadzone badania wykazały, że w przypadku lakierów z żywic sztucznych zastosowanie 10\% lub 20\% stężenia żywicy w roztworze nie ma istotnego wpływu na przyczepność.

\section{Lakiery z żywic sztucznych z dodatkiem eteru metylowego glikolu dipropylenowego}

Lakiery z żywic syntetycznych modyfikowano dodatkiem eteru metylowego glikolu dipropylenowego w celu przedłużenia czasu możliwości równomiernego rozprowadzania lakieru po powierzchni.

Tab. 2. Lakiery z żywic sztucznych z dodatkiem eteru metylowego glikolu dipropylenowego - badanie po 5 miesiącach od nałożenia (temp. $22^{\circ} \mathrm{C}$, wilg. $40 \%$ )

\begin{tabular}{|c|c|c|c|}
\hline $\mathrm{Nr}$ & Nazwa lakieru/kompozycji & Wynik & Uwagi \\
\hline 1 & 2 & 3 & 4 \\
\hline 21 & $\begin{array}{l}\text { 14\% Paraloid B-44 w acetonie + } \\
\text { eter metylowy glikolu dipropylenowego (2:1) }\end{array}$ & 5,0 & Warstwa odpada w formie błony prawie w całości \\
\hline 22 & $\begin{array}{l}14 \% \text { Paraloid B-44 w toluenie + } \\
\text { eter metylowy glikolu dipropylenowego }(2: 1)+ \\
\text { barwnik żółty Savinyl, RLSN Clariant }\end{array}$ & 4,1 & $\begin{array}{l}\text { Powierzchnia błyszcząca. Po oderwaniu taśmy } \\
\text { bez zmian }\end{array}$ \\
\hline 23 & $\begin{array}{l}\text { 14\% Paraloid B-44 w 1-1-metoksy-2-propanolu + } \\
\text { eter metylowy glikolu dipropylenowego }(2: 1)+ \\
\text { barwnik żółty Savinyl, RLSN Clariant }\end{array}$ & 4,3 & Warstwa odpada w formie błony \\
\hline 24 & $\begin{array}{l}14 \% \text { Paraloid B-48N w acetonie + } \\
\text { eter metylowy glikolu dipropylenowego }(2: 1)+ \\
\text { barwnik żółty Savinyl, RLSN Clariant }\end{array}$ & 0,0 & $\begin{array}{l}\text { Powierzchnia błyszcząca. Po oderwaniu taśmy } \\
\text { bez zmian }\end{array}$ \\
\hline 25 & $\begin{array}{l}14 \% \text { Paraloid B-48N w toluenie + } \\
\text { eter metylowy glikolu dipropylenowego }(2: 1)+ \\
\text { barwnik żółty Savinyl, RLSN Clariant }\end{array}$ & 0,0 & $\begin{array}{l}\text { Powierzchnia błyszcząca. Po oderwaniu taśmy } \\
\text { bez zmian }\end{array}$ \\
\hline 26 & $\begin{array}{l}14 \% \text { Paraloid B-72 w toluenie + } \\
\text { eter metylowy glikolu dipropylenowego }(2: 1)+ \\
\text { barwnik żółty Savinyl, RLSN Clariant }\end{array}$ & 0,4 & $\begin{array}{l}\text { Powierzchnia błyszcząca. Po oderwaniu taśmy } \\
\text { bez zmian }\end{array}$ \\
\hline 27 & $\begin{array}{l}\text { 14\% Laropal A } 81 \text { w alkoholu etylowym + eter } \\
\text { metylowy glikolu dipropylenowego }(2: 1)\end{array}$ & 1,4 & $\begin{array}{l}\text { Powierzchnia błyszcząca. Po oderwaniu taśmy } \\
\text { lekko matowa }\end{array}$ \\
\hline
\end{tabular}


Ciag dalszy tab. 2

\begin{tabular}{|c|l|c|l|}
\hline 1 & \multicolumn{1}{|c|}{2} & 3 & \multicolumn{1}{|c|}{4} \\
\hline 28 & $\begin{array}{l}11 \% \text { Paraloid B-48N w 1-metoksy-2-propanolu } \\
\text { eter metylowy glikolu dipropylenowego (1:1) } \\
\text { barwnik źółty Savinyl, RLSN Clariant }\end{array}$ & 0,0 & $\begin{array}{l}\text { Powierzchnia błyszcząca. Po oderwaniu taśmy } \\
\text { bez zmian. Bardzo dobra przyczepność }\end{array}$ \\
\hline 29 & $\begin{array}{l}11 \% \text { Paraloid B-72 w acetonie + eter metylowy } \\
\text { glikolu dipropylenowego (1:1) + barwnik żółty } \\
\text { Savinyl, RLSN Clariant }\end{array}$ & 0,8 & $\begin{array}{l}\text { Powierzchnia błyszcząca. Po oderwaniu taśmy } \\
\text { bez zmian }\end{array}$ \\
\hline 30 & $\begin{array}{l}11 \% \text { Paraloid B-72 w alkoholu etylowym + } \\
\text { eter metylowy glikolu dipropylenowego (1:1) } \\
\text { barwnik źółty Savinyl, RLSN Clariant }\end{array}$ & 1,2 & $\begin{array}{l}\text { Powierzchnia błyszcząca. Po oderwaniu taśmy } \\
\text { bez zmian }\end{array}$ \\
\hline 31 & $\begin{array}{l}11 \% \text { Paraloid B-82 w acetonie + eter metylowy } \\
\text { glikolu dipropylenowego (1:1) }\end{array}$ & 1,8 & $\begin{array}{l}\text { Powierzchnia błyszcząca. Po oderwaniu taśmy } \\
\text { bez zmian }\end{array}$ \\
\hline 32 & $\begin{array}{l}11 \% \text { Paraloid B-82 w toluenie + eter metylowy } \\
\text { glikolu dipropylenowego (1:1) }\end{array}$ & 2,4 & $\begin{array}{l}\text { Powierzchnia błyszcząca. Po oderwaniu taśmy } \\
\text { bez zmian }\end{array}$ \\
\hline 33 & $\begin{array}{l}11 \% \text { Paraloid B-82 w alkoholu etylowym + eter } \\
\text { metylowy glikolu dipropylenowego (1:1) }\end{array}$ & 1,8 & $\begin{array}{l}\text { Powierzchnia błyszcząca. Po oderwaniu taśmy } \\
\text { bez zmian }\end{array}$ \\
\hline 34 & $\begin{array}{l}11 \% \text { Laropal A 81 w acetonie + eter metylowy } \\
\text { glikolu dipropylenowego (1:1) }\end{array}$ & 0,3 & $\begin{array}{l}\text { Powierzchnia błyszcząca. Po oderwaniu taśmy } \\
\text { lekko matowa. Warstwa krucha }\end{array}$ \\
\hline 35 & $\begin{array}{l}11 \% \text { Laropal A 81 w toluenie + eter metylowy } \\
\text { glikolu dipropylenowego (1:1) }\end{array}$ & 1,2 & $\begin{array}{l}\text { Powierzchnia błyszcząca. Po oderwaniu taśmy } \\
\text { lekko matowa. Warstwa krucha }\end{array}$ \\
\hline
\end{tabular}

Dodatek do lakierów eteru metylowego glikolu dipropylenowego nie wpłynął negatywnie na ich przyczepność do podłoża.

\section{Lakiery z żywic naturalnych}

Przy badaniu lakierów na bazie żywic naturalnych zastosowano 10\% i $20 \%$ stężenia w celu określenia wpływu stężenia na przyczepność.

Tab. 3. Lakiery z żywic naturalnych - badanie po 5 miesiącach od nałożenia (temp. $21^{\circ} \mathrm{C}$, wilg. $40 \%$ )

\begin{tabular}{|c|c|c|l|}
\hline $\mathrm{Nr}$ & Nazwa lakieru/kompozycji & Wynik & \multicolumn{1}{|c|}{ Uwagi } \\
\hline 1 & 2 & 3 & 4 \\
\hline 36 & $20 \%$ Szelak bielony w alkoholu etylowym & 0,5 & $\begin{array}{l}\text { Powierzchnia błyszcząca. Po oderwaniu taśmy bez } \\
\text { zmian. Przy grubszej warstwie bardziej widoczne } \\
\text { kruszenie się brzegów }\end{array}$ \\
\hline 36 & $10 \%$ Szelak bielony w alkoholu etylowym & 0,3 & $\begin{array}{l}\text { Białe smugi w warstwie - wynik zbyt szybkiego } \\
\text { nałożenia, po rozcieńczeniu 20\% lakieru }\end{array}$ \\
\hline 37 & $20 \%$ Szelak bielony w alkoholu butylowym & 0,2 & $\begin{array}{l}\text { Powierzchnia błyszcząca. Po oderwaniu taśmy bez } \\
\text { zmian. Przy grubszej warstwie bardziej widoczne } \\
\text { kruszenie się brzegów }\end{array}$ \\
\hline 37 & $10 \%$ Szelak bielony w alkoholu butylowym & 0,2 & $\begin{array}{l}\text { Powierzchnia błyszcząca. Po oderwaniu taśmy } \\
\text { bez zmian }\end{array}$ \\
\hline
\end{tabular}


Ciag dalszy tab. 3

\begin{tabular}{|c|c|c|c|}
\hline 1 & 2 & 3 & 4 \\
\hline 38 & $\begin{array}{l}20 \% \text { Szelak bielony w 1-metoksy-2-pro- } \\
\text { panolu }\end{array}$ & 0,3 & $\begin{array}{l}\text { Powierzchnia błyszcząca. Po oderwaniu taśmy bez } \\
\text { zmian. Przeprowadzono również próbę z lakierem } \\
\text { zabarwionym, wynik analogiczny }\end{array}$ \\
\hline 39 & $\begin{array}{l}20 \% \text { Szelak złocisty (nieodwoskowany) } \\
\text { w alkoholu etylowym }\end{array}$ & 0,3 & $\begin{array}{l}\text { Powierzchnia błyszcząca. Po oderwaniu taśmy } \\
\text { bez zmian }\end{array}$ \\
\hline $39^{\prime}$ & $\begin{array}{l}10 \% \text { Szelak złocisty (nieodwoskowany) } \\
\text { w alkoholu etylowym }\end{array}$ & 0,2 & $\begin{array}{l}\text { Białe smugi w warstwie - wynik zbyt szybkiego } \\
\text { nałożenia, po rozcieńczeniu } 20 \% \text { lakieru }\end{array}$ \\
\hline 40 & $\begin{array}{l}20 \% \text { Szelak złocisty (nieodwoskowany) } \\
\text { w alkoholu butylowym }\end{array}$ & 0,5 & $\begin{array}{l}\text { Warstwa błyszcząca. Po oderwaniu taśmy bez } \\
\text { zmian }\end{array}$ \\
\hline 40 ' & $\begin{array}{l}10 \% \text { Szelak złocisty (nieodwoskowany) } \\
\text { w alkoholu butylowym }\end{array}$ & 0,5 & $\begin{array}{l}\text { Warstwa błyszcząca. Po oderwaniu taśmy bez } \\
\text { zmian }\end{array}$ \\
\hline 41 & $\begin{array}{l}20 \% \text { Szelak pomarańczowy (nieodwoskowa- } \\
\text { ny) w 1-metoksy-2-propanolu }\end{array}$ & 0,3 & $\begin{array}{l}\text { Powierzchnia błyszcząca. Po oderwaniu taśmy } \\
\text { bez zmian }\end{array}$ \\
\hline 42 & $\begin{array}{l}20 \% \text { Szelak rubinowy w 1-metoksy-2-pro- } \\
\text { panolu }\end{array}$ & 0,5 & $\begin{array}{l}\text { Powierzchnia błyszcząca. Po oderwaniu taśmy } \\
\text { bez zmian }\end{array}$ \\
\hline 43 & $20 \%$ Sandarak w alkoholu etylowym & 1,5 & $\begin{array}{l}\text { Warstwa błyszcząca. Po oderwaniu taśmy lekko } \\
\text { matowa }\end{array}$ \\
\hline $43^{\prime}$ & $10 \%$ Sandarak w alkoholu etylowym & 0,8 & $\begin{array}{l}\text { Białe smugi w lakierze - wynik zbyt szybkiego } \\
\text { nałożenia, po rozcieńczeniu } 20 \%\end{array}$ \\
\hline 44 & $20 \%$ Sandarak w alkoholu butylowym & 1,3 & $\begin{array}{l}\text { Warstwa błyszcząca. Po oderwaniu taśmy lekko } \\
\text { matowa }\end{array}$ \\
\hline $44^{\prime}$ & $10 \%$ Sandarak w alkoholu butylowym & 1,5 & $\begin{array}{l}\text { Warstwa błyszcząca. Po oderwaniu taśmy lekko } \\
\text { matowa }\end{array}$ \\
\hline 45 & $20 \%$ Sandarak w 1-metoksy-2-propanolu & 1,8 & $\begin{array}{l}\text { Powierzchnia błyszcząca. Po oderwaniu taśmy } \\
\text { lekko matowa }\end{array}$ \\
\hline 46 & $\begin{array}{l}20 \% \text { Żywica benzoesowa w alkoholu } \\
\text { etylowym }\end{array}$ & 1,4 & $\begin{array}{l}\text { Warstwa błyszcząca. Po oderwaniu taśmy lekko } \\
\text { matowa }\end{array}$ \\
\hline $46^{\prime}$ & $\begin{array}{l}10 \% \text { Żywica benzoesowa w alkoholu } \\
\text { etylowym }\end{array}$ & 1,6 & $\begin{array}{l}\text { Warstwa błyszcząca. Po oderwaniu taśmy lekko } \\
\text { matowa }\end{array}$ \\
\hline
\end{tabular}

Przeprowadzone badania wykazały, że w przypadku lakierów z żywic naturalnych zastosowanie $10 \%$ lub $20 \%$ stężenia żywicy w roztworze nie ma wpływu na przyczepność. Jeżeli zmniejszamy stężenie lakieru z 20\% na niższe, np. 10\%, należy lakier dobrze wymieszać i dać możliwość przereagowania wszystkich składników, w przeciwnym razie moga bowiem wystapić zmatowienia i zabielenia w warstwie. 


\section{Lakiery z żywic naturalnych z dodatkiem eteru metylowego glikolu dipropylenowego}

Lakiery z żywic naturalnych modyfikowano dodatkiem eteru metylowego glikolu dipropylenowego w celu przedłużenia czasu możliwości równomiernego rozprowadzania lakieru po powierzchni.

Tab. 4. Lakiery na bazie żywic naturalnych z dodatkiem eteru metylowego glikolu dipropylenowego - badanie po 5 miesiącach od nałożenia (temp. $23^{\circ} \mathrm{C}$, wilg. $40 \%$ )

\begin{tabular}{|c|l|c|l|}
\hline $\mathrm{Nr}$ & \multicolumn{1}{|c|}{ Nazwa lakieru/kompozycji } & Wynik & \multicolumn{1}{|c|}{ Uwagi } \\
\hline 44 & $\begin{array}{l}11 \% \text { Szelak bielony w alkoholu etylowym + eter } \\
\text { metylowy glikolu dipropylenowego (1:1) } \\
+ \text { barwnik źółty Savinyl, RLSN Clariant }\end{array}$ & 0,3 & $\begin{array}{l}\text { Powierzchnia błyszcząca. Po oderwaniu taśmy } \\
\text { bez zmian }\end{array}$ \\
\hline 45 & $\begin{array}{l}11 \% \text { Szelak bielony w alkoholu butylowym + eter } \\
\text { metylowy glikolu dipropylenowego (1:1) }\end{array}$ & 0,0 & $\begin{array}{l}\text { Powierzchnia błyszcząca. Po oderwaniu taśmy } \\
\text { bez zmian }\end{array}$ \\
\hline 46 & $\begin{array}{l}11 \% \text { Szelak złocisty (nieodwoskowany) } \\
\text { w alkoholu etylowym + eter metylowy glikolu } \\
\text { dipropylenowego (1:1) + barwnik żółty Savinyl, } \\
\text { RLSN Clariant }\end{array}$ & 0,5 & $\begin{array}{l}\text { Powierzchnia błyszcząca. Po oderwaniu taśmy } \\
\text { bez zmian }\end{array}$ \\
\hline 47 & $\begin{array}{l}11 \% \text { Szelak złocisty (nieodwoskowany) } \\
\text { w alkoholu butylowym + eter metylowy glikolu } \\
\text { dipropylenowego (1:1) + barwnik żółty Savinyl, } \\
\text { RLSN Clariant }\end{array}$ & 0,5 & $\begin{array}{l}\text { Powierzchnia błyszcząca. Po oderwaniu taśmy } \\
\text { bez zmian }\end{array}$ \\
\hline 48 & $\begin{array}{l}11 \% \text { Sandarak w alkoholu etylowym + eter me- } \\
\text { tylowy glikolu dipropylenowego (1:1) + barwnik } \\
\text { żółty Savinyl, RLSN Clariant }\end{array}$ & 1,3 & $\begin{array}{l}\text { Powierzchnia błyszcząca. Po oderwaniu taśmy } \\
\text { bez zmian. Bardziej kruchy niż lakiery szelakowe }\end{array}$ \\
\hline 49 & $\begin{array}{l}11 \% \text { Sandarak w alkoholu butylowym + eter } \\
\text { metylowy glikolu dipropylenowego }\end{array}$ & 1,2 & $\begin{array}{l}\text { Powierzchnia błyszcząca. Po oderwaniu taśmy } \\
\text { delikatne zmatowienie }\end{array}$ \\
\hline 50 & $\begin{array}{l}11 \% \text { Żywica benzoesowa w alkoholu etylowym + } \\
\text { eter metylowy glikolu dipropylenowego }\end{array}$ & 1,2 & $\begin{array}{l}\text { Powierzchnia błyszcząca. Po oderwaniu taśmy } \\
\text { delikatne zmatowienie }\end{array}$ \\
\hline
\end{tabular}

\section{Kompozycje lakierów z żywic naturalnych}

Badaniom poddano również lakiery sporządzone na podstawie receptur zawartych w dawnych traktatach ${ }^{5}$ W poniższych tabelach, obok składu lakieru, przedstawiono stosunek wagowy poszczególnych składników.

5 Kompozycje lakierów na podstawie receptur zawartych w traktatach Watina i De Mayerna. J. P. Watin, Nauka teoretyczno-praktyczna sztuki malarza, pozłacarza i lakiernika, tłum. W. Siekierzyński, Wilno 1854. Tytuł oryg. (francuski) - L’art du peittre, doreur, vernisseur (1754). E. Berger, Quellen für Maltechnik, während der Renaissance und de- 
Tab. 5. Kompozycje lakierów z żywic naturalnych - badanie po 5 miesiącach od nałożenia (temp. $21^{\circ} \mathrm{C}$, wilg. $40 \%$ )

\begin{tabular}{|c|c|c|c|}
\hline $\mathrm{Nr}$ & Nazwa lakieru/kompozycji & Wynik & Uwagi \\
\hline 51 & $\begin{array}{l}\text { Szelak jasny (odwoskowany), sandarak, } \\
\text { terpentyna wenecka w alkoholu etylowym } \\
(6: 2: 1: 18)\end{array}$ & 1,6 & $\begin{array}{l}\text { Powierzchnia błyszcząca. Po oderwaniu taśmy } \\
\text { bez zmian }\end{array}$ \\
\hline 52 & $\begin{array}{l}\text { Szelak pomarańczowy, sandarak, terpentyna } \\
\text { wenecka w alkoholu etylowym }(6: 2: 1: 18)\end{array}$ & 1,6 & $\begin{array}{l}\text { Powierzchnia błyszcząca. Po oderwaniu taśmy } \\
\text { bez zmian }\end{array}$ \\
\hline 53 & $\begin{array}{l}\text { Szelak rubinowy, sandarak, terpentyna } \\
\text { wenecka w alkoholu etylowym }\end{array}$ & 2,2 & $\begin{array}{l}\text { Powierzchnia błyszcząca. Po oderwaniu taśmy } \\
\text { bez zmian }\end{array}$ \\
\hline 54 & $\begin{array}{l}\text { Szelak rubinowy, terpentyna wenecka w alko- } \\
\text { holu etylowym }(6: 2: 1: 18)\end{array}$ & 2,3 & $\begin{array}{l}\text { Powierzchnia błyszcząca. Po oderwaniu taśmy } \\
\text { delikatne zmatowienie }\end{array}$ \\
\hline 55 & $\begin{array}{l}\text { Szelak rubinowy, terpentyna wenecka w alko- } \\
\text { holu butylowym (1:10:9) }\end{array}$ & 2,5 & $\begin{array}{l}\text { Powierzchnia błyszcząca. Po oderwaniu taśmy } \\
\text { delikatne zmatowienie }\end{array}$ \\
\hline 56 & $\begin{array}{l}\text { Szelak rubinowy, olejek lawendowy w alkoho- } \\
\text { lu butylowym (1:4:9) }\end{array}$ & 0,3 & $\begin{array}{l}\text { Powierzchnia błyszcząca. Po oderwaniu taśmy } \\
\text { bez zmian }\end{array}$ \\
\hline 57 & $\begin{array}{l}\text { Sandarak, terpentyna wenecka, olej Iniany, } \\
\text { olejek lawendowy w alkoholu etylowym } \\
(24: 16: 8: 1: 36)\end{array}$ & 3,3 & $\begin{array}{l}\text { Powierzchnia błyszcząca. Po oderwaniu taśmy } \\
\text { delikatne zmatowienie }\end{array}$ \\
\hline 58 & $\begin{array}{l}\text { Sandarak, terpentyna wenecka w alkoholu } \\
\text { etylowym }(4: 3: 16)\end{array}$ & 2,3 & $\begin{array}{l}\text { Powierzchnia błyszcząca. Po oderwaniu taśmy } \\
\text { delikatne zmatowienie }\end{array}$ \\
\hline 59 & $\begin{array}{l}\text { Sandarak, mastyks, terpentyna wenecka, } \\
\text { elemi } \\
\text { w alkoholu etylowym (8:2:3:1:32) } \\
\end{array}$ & 2,4 & $\begin{array}{l}\text { Powierzchnia błyszcząca. Po oderwaniu taśmy } \\
\text { delikatne zmatowienie }\end{array}$ \\
\hline 60 & $\begin{array}{l}\text { Sandarak, mastyks, terpentyna wenecka } \\
\text { w alkoholu etylowym (16:2:4:32) } \\
\end{array}$ & 2,4 & $\begin{array}{l}\text { Powierzchnia błyszcząca. Po oderwaniu taśmy } \\
\text { delikatne zmatowienie }\end{array}$ \\
\hline 61 & $\begin{array}{l}\text { Sandarak, szelak pomarańczowy, kalafonia, } \\
\text { terpentyna wenecka w alkoholu etylowym } \\
(8: 2: 4: 6: 32)\end{array}$ & 2,4 & $\begin{array}{l}\text { Powierzchnia błyszcząca. Po oderwaniu taśmy } \\
\text { delikatne zmatowienie }\end{array}$ \\
\hline 62 & $\begin{array}{l}\text { Sandarak, szelak, mastyks, elemi, terpentyna } \\
\text { wenecka w alkoholu etylowym }(4: 2: 2: 1: 2: 32)\end{array}$ & 2,0 & $\begin{array}{l}\text { Powierzchnia błyszcząca. Po oderwaniu taśmy } \\
\text { delikatne zmatowienie }\end{array}$ \\
\hline
\end{tabular}

\section{Lakiery olejno-żywiczne}

Zanalizowano także kompozycje lakierów olejno-żywicznych sporządzone na podstawie receptur z dawnych traktatów i współczesnych.

ren folgezeiten nebst dem De Mayerne Manuskript, Beiträge zur Entwickelungs-Geschichte der Maltechnik, IV Folge, Verlag von Georg D. W. Callwey, München 1901; T. De Mayerne, Pictoria, sculptoria et quae subalternarum artum, tłum. w Zakładzie Technologii i Technik Malarskich IZiK UMK w Toruniu. 
Tab. 6. Kompozycje lakierów olejno-żywicznych - badanie po 5 miesiącach od nałożenia (temp. $21^{\circ} \mathrm{C}$, wilg. $40 \%$ )

\begin{tabular}{|c|c|c|c|}
\hline $\mathrm{Nr}$ & Nazwa lakieru/kompozycji & Wynik & Uwagi \\
\hline 63 & $\begin{array}{l}\text { Olej Iniany, mastyks w olejku terpentynowym + } \\
\text { sykatywa kobaltowa (1:1:1) }\end{array}$ & 3,5 & $\begin{array}{l}\text { Powierzchnia błyszcząca. Po oderwaniu taśmy } \\
\text { bez zmian. Warstwa krucha, odpada niewielkimi } \\
\text { łuskami }\end{array}$ \\
\hline 64 & $\begin{array}{l}\text { Olej Iniany, mastyks w olejku terpentynowym } \\
(1: 1: 1)\end{array}$ & 4,3 & $\begin{array}{l}\text { Powierzchnia błyszcząca. Po oderwaniu taśmy } \\
\text { bez zmian }\end{array}$ \\
\hline 65 & $\begin{array}{l}\text { Kopal z Madagaskaru, olej Iniany (z sykatywą } \\
\text { kobaltową) w olejku terpentynowym (2:1:2) }\end{array}$ & 3,4 & $\begin{array}{l}\text { Powierzchnia błyszcząca. Po oderwaniu taśmy } \\
\text { bez zmian }\end{array}$ \\
\hline 66 & $\begin{array}{l}\text { Kopal z Madagaskaru, olej Iniany (z sykatywą } \\
\text { kobaltową) w olejku terpentynowym (2:1:4) }\end{array}$ & 2,2 & $\begin{array}{l}\text { Powierzchnia błyszcząca. Po oderwaniu taśmy bez } \\
\text { zmian. Cieńsza warstwa ma lepszą przyczepność }\end{array}$ \\
\hline 67 & $\begin{array}{l}\text { Kopal z Madagaskaru, olej Iniany (sykatywo- } \\
\text { wany, Kremer) w olejku terpentynowym (2:1:2) }\end{array}$ & 3,2 & $\begin{array}{l}\text { Powierzchnia błyszcząca. Po oderwaniu taśmy } \\
\text { bez zmian }\end{array}$ \\
\hline 68 & $\begin{array}{l}\text { Kopal z Madagaskaru, olej Iniany (sykatywo- } \\
\text { wany, Kremer) w olejku terpentynowym (2:1:4) }\end{array}$ & 3,8 & $\begin{array}{l}\text { Powierzchnia błyszcząca. Po oderwaniu taśmy bez } \\
\text { zmian. Cieńsza warstwa ma lepszą przyczepność }\end{array}$ \\
\hline 70 & $\begin{array}{l}\text { Bursztyn, olej Iniany (z sykatywą kobaltową) } \\
\text { w olejku terpentynowym (2:1:4) }\end{array}$ & 0,5 & $\begin{array}{l}\text { Powierzchnia błyszcząca. Po oderwaniu taśmy } \\
\text { bez zmian. Bardzo dobra przyczepność. Gładkie } \\
\text { krawędzie }\end{array}$ \\
\hline 71 & $\begin{array}{l}\text { Lakier damarowo-olejny (olej sykatywowany, } \\
\text { Kremer) w olejku terpentynowym (2:3:3) }\end{array}$ & 0,3 & $\begin{array}{l}\text { Powierzchnia błyszcząca. Po oderwaniu taśmy } \\
\text { bez zmian }\end{array}$ \\
\hline 72 & $\begin{array}{l}\text { Lakier mastyksowo-olejny (olej sykatywowany, } \\
\text { Kremer) w olejku terpentynowym (2:3:3) + } \\
\text { farba olejna Indian Yellow }\end{array}$ & 0,3 & $\begin{array}{l}\text { Powierzchnia półmatowa. Po oderwaniu taśmy } \\
\text { bez zmian }\end{array}$ \\
\hline 73 & $\begin{array}{l}\text { Lakier damarowo-olejny (olej sykatywowany } \\
\text { kobaltem) w olejku terpentynowym (2:3:3) } \\
\text { (gotowany) }\end{array}$ & 0,3 & $\begin{array}{l}\text { Powierzchnia półmatowa. Po oderwaniu taśmy } \\
\text { bez zmian }\end{array}$ \\
\hline
\end{tabular}

\section{Gotowe lakiery (dostępne w handlu)}

Tab. 7. Produkty handlowe - badanie po 5 miesiącach od nałożenia (temp. $23^{\circ} \mathrm{C}$, wilg. $40 \%$ )

\begin{tabular}{|c|l|c|l|}
\hline $\mathrm{Nr}$ & \multicolumn{1}{|c|}{ Nazwa lakieru/kompozycji } & Wynik & \multicolumn{1}{|c|}{ Uwagi } \\
\hline 1 & \multicolumn{1}{|c|}{2} & 3 & \multicolumn{1}{|c|}{4} \\
\hline 77 & Acrylic Varnish Picture Glossy 114 (Talens) & 0,7 & $\begin{array}{l}\text { Powierzchnia błyszcząca. Po oderwaniu taśmy } \\
\text { bez zmian }\end{array}$ \\
\hline 78 & Dammar Varnish Glossy 081 (Talens) & 2,7 & $\begin{array}{l}\text { Powierzchnia błyszcząca. Po oderwaniu taśmy } \\
\text { lekkie zmatowienie }\end{array}$ \\
\hline 79 & Picture Varnish Glossy 002 (Talens) & 2,9 & $\begin{array}{l}\text { Powierzchnia błyszcząca. Po oderwaniu taśmy } \\
\text { lekkie zmatowienie }\end{array}$ \\
\hline 80 & Bernsteinlack echt (Kremer) & 1,0 & $\begin{array}{l}\text { Powierzchnia błyszcząca. Po oderwaniu taśmy } \\
\text { bez zmian }\end{array}$ \\
\hline 81 & Szelak - lakier szelakowy dystrybucja Edan16 & 2,7 & $\begin{array}{l}\text { Powierzchnia błyszcząca. Po oderwaniu taśmy } \\
\text { bez zmian }\end{array}$ \\
\hline 82 & Lustrina Restaurarte & 3,0 & $\begin{array}{l}\text { Powierzchnia błyszcząca. Po oderwaniu taśmy } \\
\text { bez zmian }\end{array}$ \\
\hline 83 & Vernice Mecca Restaurarte & 2,3 & $\begin{array}{l}\text { Powierzchnia błyszcząca. Po oderwaniu taśmy } \\
\text { lekkie zmatowienie }\end{array}$ \\
\hline
\end{tabular}


Ciagg dalszy tab. 7

\begin{tabular}{|c|l|c|l|}
\hline 1 & \multicolumn{1}{|c|}{2} & 3 & \multicolumn{1}{|c|}{4} \\
\hline 84 & Glass Decorfin (Yellow 200) Talens & 0,5 & $\begin{array}{l}\text { Powierzchnia błyszcząca. Po oderwaniu taśmy } \\
\text { bez zmian }\end{array}$ \\
\hline 84, & $\begin{array}{l}\text { Glass Decorfin (Yellow 200) Talens + benzyna } \\
\text { lakowa }\end{array}$ & 0,3 & $\begin{array}{l}\text { Powierzchnia błyszcząca. Po oderwaniu taśmy } \\
\text { bez zmian }\end{array}$ \\
\hline 85 & Zaponlack Kremer & 0,3 & $\begin{array}{l}\text { Powierzchnia błyszcząca. Po oderwaniu taśmy } \\
\text { bez zmian. Zjawisko iryzacji powierzchni }\end{array}$ \\
\hline 86 & Incral 44 & 2,6 & $\begin{array}{l}\text { Powierzchnia błyszcząca. Po oderwaniu taśmy } \\
\text { lekkie zmatowienie }\end{array}$ \\
\hline 87 & Idea Vetro (070 Yellow) & 2,5 & $\begin{array}{l}\text { Powierzchnia błyszcząca. Po oderwaniu taśmy } \\
\text { bez zmian }\end{array}$ \\
\hline 88 & Mikstion 3h Lefranck & 0,0 & Bardzo dobra przyczepność \\
\hline 89 & Białko jajka & 0,7 & $\begin{array}{l}\text { Widoczne ogniska korozji, bardzo cienka } \\
\text { warstwa }\end{array}$ \\
\hline
\end{tabular}

\section{Gotowe lakiery z dodatkiem eteru metylowego glikolu dipropylenowego}

W celu przedłużenia czasu równomiernego rozprowadzania do lakierów dodano eter metylowy glikolu dipropylenowego.

Tab. 8. Produkty handlowe $\mathrm{z}$ dodatkiem eteru metylowego glikolu dipropylenowego - badanie po 5 miesiącach od nałożenia (temp. $22^{\circ} \mathrm{C}$, wilg. $40 \%$ )

\begin{tabular}{|c|l|c|l|}
\hline $\mathrm{Nr}$ & \multicolumn{1}{|c|}{ Nazwa lakieru/kompozycji } & Wynik & \multicolumn{1}{|c|}{ Uwagi } \\
\hline 90 & $\begin{array}{l}\text { Szelak - lakier (Edan) + eter metylowy glikolu } \\
\text { dipropylenowego (1:1) }\end{array}$ & 0,8 & $\begin{array}{l}\text { Powierzchnia błyszcząca. Po oderwaniu taśmy } \\
\text { bez zmian }\end{array}$ \\
\hline 91 & $\begin{array}{l}\text { Lustrina Restaurarte + eter metylowy glikolu } \\
\text { dipropylenowego (2:1) }\end{array}$ & 0,9 & $\begin{array}{l}\text { Powierzchnia błyszcząca. Po oderwaniu taśmy } \\
\text { bez zmian }\end{array}$ \\
\hline 92 & $\begin{array}{l}\text { Vernice Mecca Restaurarte + eter metylowy } \\
\text { glikolu dipropylenowego (2:1) }\end{array}$ & 2,0 & $\begin{array}{l}\text { Powierzchnia błyszcząca. Po oderwaniu taśmy } \\
\text { bez zmian }\end{array}$ \\
\hline 93 & $\begin{array}{l}\text { Zaponlack + eter metylowy glikolu dipropyle- } \\
\text { nowego (3:1) + barwnik żółty Savinyl, RLSN } \\
\text { Clariant }\end{array}$ & 0,2 & $\begin{array}{l}\text { Powierzchnia błyszcząca. Po oderwaniu taśmy } \\
\text { bez zmian }\end{array}$ \\
\hline 93 & $\begin{array}{l}\text { Zaponlack + eter metylowy glikolu dipropyle- } \\
\text { nowego (1:1) + barwnik żółty Savinyl, RLSN } \\
\text { Clariant }\end{array}$ & 0,2 & $\begin{array}{l}\text { Powierzchnia błyszcząca. Po oderwaniu taśmy } \\
\text { bez zmian }\end{array}$ \\
\hline 94 & $\begin{array}{l}\text { Incral 44 + eter metylowy glikolu dipropylenowe- } \\
\text { go (3:1) + barwnik źółty Savinyl, RLSN Clariant }\end{array}$ & 1,3 & $\begin{array}{l}\text { Powierzchnia błyszcząca. Po oderwaniu taśmy } \\
\text { bez zmian }\end{array}$ \\
\hline 94 & $\begin{array}{l}\text { Incral 44 + eter metylowy glikolu dipropylenowe- } \\
\text { go (1:1) + barwnik źółty Savinyl, RLSN Clariant }\end{array}$ & 0,8 & $\begin{array}{l}\text { Powierzchnia błyszcząca. Po oderwaniu taśmy } \\
\text { bez zmian }\end{array}$ \\
\hline 95 & $\begin{array}{l}\text { Idea Vetro (070 Yellow) + eter metylowy glikolu } \\
\text { dipropylenowego (3:1) }\end{array}$ & 2,1 & $\begin{array}{l}\text { Powierzchnia błyszcząca. Po oderwaniu taśmy } \\
\text { bez zmian }\end{array}$ \\
\hline
\end{tabular}


Dodatek do lakierów eteru metylowego glikolu dipropylenowego nie wpłynął negatywnie na ich przyczepność do podłoża.

\section{Podsumowanie}

Przeprowadzone badania wykazały, że spośród lakierów sporządzonych z żywic sztucznych najlepsza przyczepność maja lakiery przygotowane z Paraloidu B-48N i Paraloidu B-67. Ten pierwszy jest zalecany przez producenta do zabezpieczania metalu ${ }^{6}$. Zaskakująco słaby wynik uzyskano przy Paraloidzie B-44, który ze względu na swoje dobre właściwości ochronne często jest stosowany do zabezpieczania folii pozłotniczych i metalu, a w przeszłości, badany przez autora niniejszej pracy tą samą metoda, wykazywał również dobra przyczepność 7 . Podobnie słabą przyczepnością charakteryzowały się Paraloidy B-72 i B-82 oraz Regalrez 1094, nieco lepszą Laropal A-81. Dwa ostatnie dają warstwy lakierów dosyć kruche. Przeprowadzone próby wykazały, że rodzaj rozpuszczalnika i stężenia nie odgrywają istotnej roli. Dodatek eteru metylowego glikolu dipropylenowego znacznie poprawia czas nanoszenia poszczególnych lakierów i nie wpływa negatywnie na przyczepność do powierzchni metalu.

Lakiery przygotowane z żywic naturalnych wykazują ogólnie dobrą przyczepność. Najlepsze rezultaty uzyskano w przypadku lakierów szelakowych, bez względu na rodzaj szelaku, zastosowany rozpuszczalnik i stężenie, nieco gorsze w przypadku lakierów sandarakowych i benzoesowych. Podobnie jak w przypadku lakierów z żywic sztucznych, dodatek eteru metylowego glikolu dipropylenowego poprawił możliwość nanoszenia i nie wpłynął negatywnie na przyczepność.

6 W handlu również jako gotowa żywica rozpuszczona w toluenie pod nazwą Paraloid B-48S. Paraloid. Thermoplastic Solution Grade \& Solid Grade Acrylic Resins. Coatings Rohm and Haas Company, 1998.

7 J. Stachera, Techniki wykonania oraz metody konserwacji i restauracji powierzchni srebrzonych i lakierowanych w rzeźbie drewnianej polichromowanej, rozprawa doktorska napisana pod kier. prof. dr Bogumily Rouby, Uniwersytet Mikołaja Kopernika w Toruniu, Wydział Sztuk Pięknych, Instytut Zabytkoznawstwa i Konserwatorstwa, Torú 2003, aneks s. 121 [egzemplarz w posiadaniu autora pracy]. 
W badaniach obejmujących kompozycje lakierów, przygotowanych na podstawie dawnych receptur, bardzo dobra przyczepność wykazał lakier o składzie: szelak rubinowy, rozpuszczony w alkoholu butylowym, z dodatkiem olejku lawendowego. Natomiast w przeciwieństwie do prostych lakierów sporządzonych z żywic naturalnych, znacznemu pogorszeniu ulega przyczepność lakierów złożonych z wielu składników, a w szczególności, jeżeli w skład lakieru wchodzi terpentyna wenecka. Lakiery olejno-żywiczne wykazują różne właściwości w zależności od procesu przygotowania.

Z gotowych produktów dostępnych w handlu warte polecenia sa: Acrylic Varnish Picture Glossy 114 (Talens), Bernsteinlack echt (Kremer), Glass Decorfin (Yellow 200) Talens, Zaponlack Kremer oraz Mikstion $3 \mathrm{~h}$ Lefranck. Dosyć słabą przyczepność, jak na lakier zalecany do zabezpieczania metalu, wykazuje Incral 44. Próby przeprowadzone na niektórych zakupionych lakierach, tj. na lakierze szelakowym, na lakierach Lustrina Restaurarte, Vernice Mecca Restaurarte, Zaponlack (Kremer), Incral 44, Idea Vetro, modyfikowanych dodatkiem eteru metylowego glikolu dipropylenowego, przyniosły zadowalający efekt. Eter ten dał możliwość równomiernego rozprowadzania lakieru po powierzchni obiektu, a przyczepność nie uległa pogorszeniu.

Należy zwrócić uwagę na to, że badania przeprowadzono po 5 miesiącach i uzyskane wyniki nie dają nam pewności, że taka sama przyczepność będzie zachowana po wielu latach. Ponadto na obiekcie przyczepność lakieru jest uzależniona od rodzaju podłoża, jego pracy, temperatury i wilgotności otoczenia w trakcie nanoszenia i późniejszej ekspozycji oraz wielu innych czynników, mogących mieć bezpośredni lub pośredni wpływ na przyczepność warstwy lakieru. Niemniej jednak badania pokazują, których lakierów z cała pewnością nie należy stosować, a negatywne efekty widać już wkrótce po użyciu. 


\section{Summary}

\section{Research on the adhesiveness of lacquers tested by the incision-net method}

This paper presents the outcome of research on the level of resistance of lacquer coatings against delamination off the support in result of cutting the surface in rectangular net pattern, penetrating through the coating to the support. The tests were executed on contemporary used lacquers based on both natural and artificial resins as well as a large number of lacquers based on historic formulas. Also some ready-made products available on the marked were tested. In the prepared lacquer compositions next to traditional solvents also 1-metoxy-2-propanol and an admixture of methyl dipropylene glycol ether were used. The use of those to dissolve natural resins was dictated by the need to find lacquers of optimal handling properties (suitable fluidity and drying time), allowing for uniform application on painted of gilded surfaces. The effects of performed texts proved satisfactory. 